\title{
Advanced lightweight materials and manufacturing processes for automotive applications
}

\begin{abstract}
Alan I. Taub and Alan A. Luo
The global automotive industry is facing challenges in several key areas, including energy, emissions, safety, and affordability. Lightweighting is one of the key strategies used to address these challenges. Maximizing the weight reduction (i.e., minimizing vehicle weight) requires a systems-engineering design optimization and iteration process that combines material properties and manufacturing processes to meet product requirements at the lowest mass and/or cost. Advanced high-strength steels, aluminum and magnesium alloys, and carbon-fiber-reinforced polymers have emerged as important materials for automotive lightweighting. This article presents examples of how coupling materials science with innovative manufacturing processes can provide lightweight solutions in automotive engineering.
\end{abstract}

\section{Introduction}

The machines that move people and goods on land, sea, and air have undergone major changes over the past 50 years, and the key enabler for the improvements has been the development of new materials and their associated manufacturing processes. Covering the broad nature of the materials and subsystems in the various transportation modes is well beyond the scope of this article. Therefore, we concentrate on automobiles, which, on an annual basis, consume the majority of the materials measured in both weight and cost used during the manufacturing of transportation machines.

\section{Automobile industry challenges}

The large economies of scale available to the automotive industry have made vehicles affordable to growing numbers of people. Henry Ford designed the Model $\mathrm{T}$ to be "a motor car for the great multitude ... so low in price that no man making a good salary will be unable to own one." ${ }^{\prime}$ By 1955, the cost of a baseline Chevrolet Bel Air (USD $\$ 1,725^{2}$ ) represented about 22 weeks of US wages. ${ }^{3}$ Affordability promoted personal mobility, and by the mid1950s, the North American auto industry was producing almost 10 million units per year (compared to about 17 million units per year today). ${ }^{4}$ Global vehicle ownership has grown even more impressively: The industry produced just over
13.5 million units in 1950, but today is approaching 80 million units. ${ }^{4}$ In 1950 , there were fewer than 60 million vehicles on the planet. Today, the number of vehicles in use around the globe stands at well over 800 million, which corresponds to approximately $12 \%$ of the world's population owning an automobile.

The dramatic growth in vehicles operated around the world has presented societal sustainability challenges, including safety, congestion, tailpipe emissions, and petroleum consumption. ${ }^{5}$ Fuel economy has emerged as a particular concern. The focus on fuel economy first surfaced when the Organization of Petroleum Exporting Countries oil crises of 1973 and 1979 drove oil and gasoline prices sharply higher. The continued volatility of oil prices, coupled with concerns surrounding $\mathrm{CO}_{2}$ emissions from the burning of fossil fuels, has made fuel economy one of the greatest challenges facing the transportation sector.

Since the invention of the powertrain over 100 years ago, the engineering community has innovated to continuously improve the internal-combustion engine. For example, the small-block 4.25-1 V8 engine in a 1955 Chevrolet produced up to $195 \mathrm{hp}(145 \mathrm{~kW})$ at a volumetric efficiency of $45 \mathrm{hp} / \mathrm{l}(34 \mathrm{~kW} / \mathrm{l})$. Ninety million engines and four generations later, the small-block engine today displaces up to 6.01 and achieves approximately $400 \mathrm{hp}(298 \mathrm{~kW})$, or roughly $70 \mathrm{hp} / 1(52 \mathrm{~kW} / \mathrm{l})$. 
The substantial improvement in power density is even more impressive when one considers that smog-forming emissions (hydrocarbons and nitrogen oxides) have been reduced by more than $99 \%$ at the same time. ${ }^{5}$ Although the progress in improving the internal-combustion engine has been impressive, the largest energy loss in an operating vehicle is from the combustion process in the engine (see Figure 1). The benchmark performance in thermal efficiency is above $30 \%$ for gasoline engines and $40 \%$ for diesels, with approaches defined to achieve an additional $5 \% .{ }^{6}$ through the introduction of partially electrified hybrids and fully electric vehicles. The materials community is being challenged to deliver improvements in all of the main components of vehicle electrification, including batteries, fuel cells, motors, and power electronics.

\section{Vehicle weight reduction goals}

A major avenue for improving vehicle efficiency, and thus fuel economy, is reducing the mass. ${ }^{7-9} \mathrm{~A}$ mid-size family car weighs about $1450 \mathrm{~kg}$, and it takes a weight reduction of approximately $150 \mathrm{~kg}$, or $10 \%$, to achieve a $6 \%$ improvement in fuel economy. As seen in Figure 2, ${ }^{9}$ following the global oil crisis of the 1970s, the weight of automobiles decreased consistently for about one decade. This was followed by a period of stable oil prices and, in the North American market, a shift to larger and heavier vehicles. Since the 1990s, engineering improvements in vehicle structural efficiency have continued, but the improvements have been offset by increased safety features and other consumer-driven content, such as convenience features and infotainment systems. More recently, ambitious fuel economy targets are being adopted worldwide, and the newest vehicle models are exhibiting weight reductions of $10 \%$ or more. Improvements in efficiency beyond that level can be achieved

Starting with user requirements of increased fuel economy, the design engineer has to integrate and prioritize the benefits of all available engineering options. The options required for weight reduction need to be compared with solutions involving increased powertrain efficiency, vehicle electrification, decreased tire rolling resistance, and improved aerodynamics. This has resulted in a general industry target for the cost of weight reduction of $\leq 4.5 \mathrm{USD} \$ /(\mathrm{kg}$ saved) ( 2 USD $\$$ [lb saved]) for weight reduction to be competitive with other fuel-economy actions. ${ }^{10}$

Cast-aluminum engine blocks met this cost target decades ago and now dominate the industry. Advanced high-strength steel (AHSS) sheet can be implemented at less than 2.2 USD\$/ ( $\mathrm{kg}$ saved) $(1 \mathrm{USD} \text { /[lb saved] })^{11}$ and is now being used regularly in body structures. Aluminum can be substituted for steel on closures (e.g., hoods and trunk lids) for less than 4 USD $\$ / k g$ (1.8 USD\$/lb). Aluminum substitution for steel on body structures costs more than $5 \mathrm{USD} \$ / \mathrm{kg}(2.3 \mathrm{USD} \$ / \mathrm{lb})$, but the recent introduction of the aluminum-bodied Ford F-150 pickup truck shows that the industry is becoming even more aggressive in utilizing advanced materials for weight reduction. ${ }^{12}$

To optimize the use of advanced materials, it is not sufficient to reduce the weight of a particular component; rather, a complete systems-engineering approach is required. Therefore, it is not surprising that the greatest weight reductions have been obtained in clean-sheet designs. Table I lists the weight reductions that can be obtained by substituting advanced lightweight materials for the baseline low-carbon steel that dominated vehicle material usage for over a century. Also reported are the percentage increases in cost associated with the material substitutions. In the following sections, we review examples of how materials scientists and engineers work collaboratively to first develop new alloys and then invent new manufacturing processes to achieve these weight reductions at the cost required to maintain the affordability of the automobile.

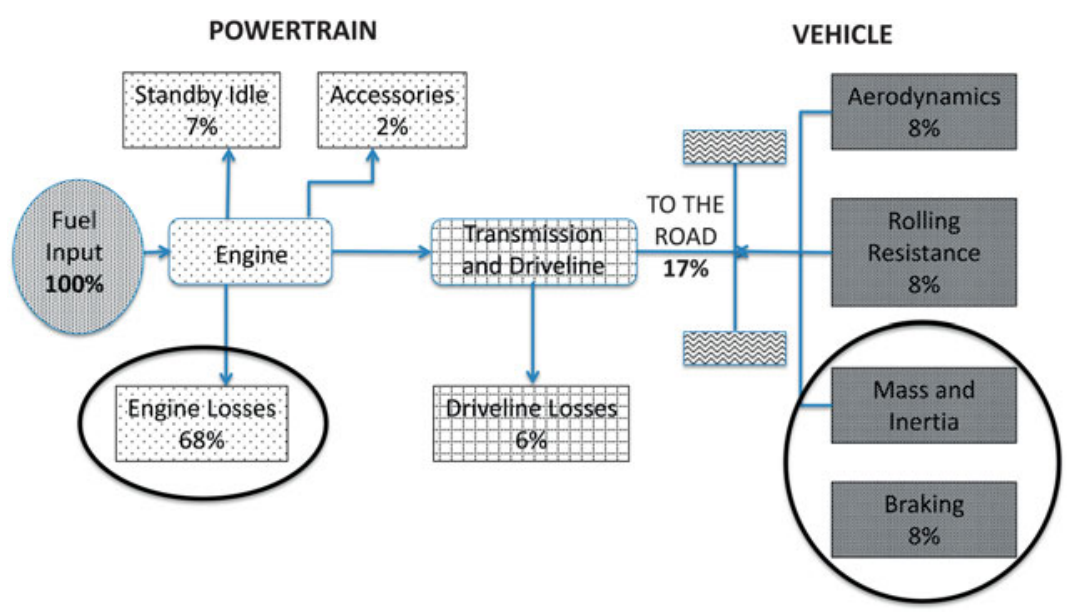

Figure 1. Typical vehicle-level energy utilization in a compact sedan with a four-cylinder engine and automatic transmission based on the US Federal Test Procedure (composite city/highway drive cycle). The circled areas show that the energy loss is highest in the engine and also that reducing vehicle mass could provide potential benefits. Figure courtesy of General Motors.

\section{Materials development Development of AHSSs}

The new AHSS steels are very attractive in offering up to a $25 \%$ weight reduction at a cost of less than USD $\$ 2$ per kilogram saved (0.9 USD\$/[lb saved]). Steels of current interest involve novel alloying and processing combinations to produce unique microstructural combinations and have been referred to by a variety of identifiers, including dual-phase (DP), transformation-induced plasticity (TRIP), high-strength low-alloy (HSLA), complexphase (CP), twinning-induced plasticity (TWIP), and martensitic steels. The properties of these multiphase steels are derived from appropriate combinations of strengthening mechanisms, the basics of which have been well developed in the steels literature. ${ }^{14-16}$ 


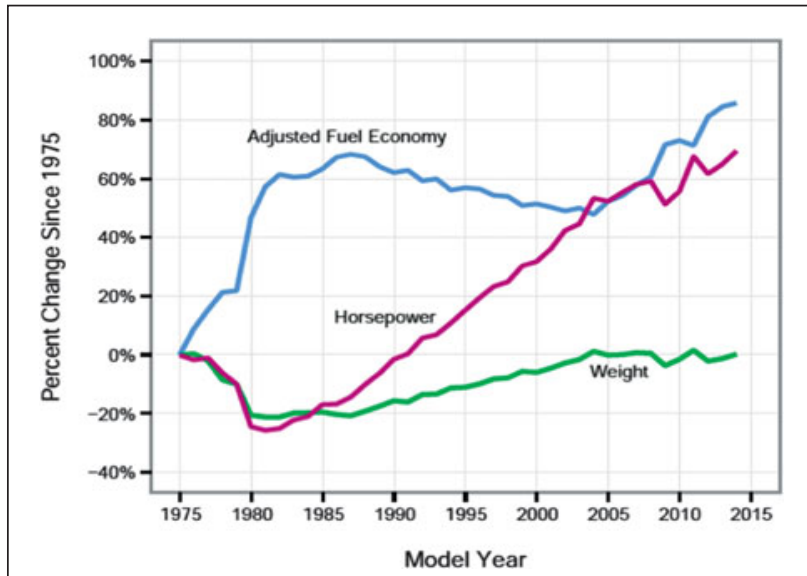

Figure 2. Changes in adjusted fuel economy, horsepower, and weight in the US automotive market for model years 1975-2014. ${ }^{9}$ Figure courtesy of the US Environmental Protection Agency.

\section{Historical AHSS developments}

Current commercially applied advanced high-strength steels evolved from significant early work on DP steels in the late 1970s and early 1980s at General Motors (GM). Figure 3, a classic figure from the work of Rashid and Rao, ${ }^{17}$ shows the effects on the mechanical properties of a conventional HSLA steel of intercritical annealing (where the metal is heated to between its lower and upper critical temperatures to allow partial transformation of the matrix into austenite) followed by quenching. The data shown are for a plain-carbon steel, an HSLA steel (SAE 980X), and the same HSLA steel after intercritical annealing and quenching to produce a DP steel (referred to as GM 980X). In contrast to the HSLA steel, the DP steel exhibits continuous yielding and a significant increase in elongation with essentially the same ultimate tensile strength.

The combination of continuous yielding with maintained or improved ductility generated significant interest and extensive research on DP steels. ${ }^{18-20}$ One important finding was the contribution of retained austenite to the deformation behavior of DP steels. Specifically, it was observed ${ }^{21}$ that DP steels contain retained austenite and the ductility of DP steels increases with increasing content of retained austenite. These findings form the basis on which new developments in AHSS for automotive applications, particularly TRIP steels, are based. second-generation AHSS. An overview of representative tensile properties, compared to those exhibited by conventional steel grades, is shown in Figure 4..$^{22,23}$ The first-generation AHSS concepts were developed in fairly dilute compositions and are primarily ferritic-based multiphase microstructures. DP steels are currently the most applied AHSS grades in the automotive industry. Interest in DP steels results from improved strength and formability, good weldability, relative ease of processing, and availability. ${ }^{24}$

Enhanced-strength/enhanced-elongation combinations are clearly obtained for TRIP steel grades, where strain-induced transformation of retained austenite into martensite results in increased strain hardening. The second-generation advanced high-strength steels clearly exhibit superior mechanical properties, but these austenitic grades are highly alloyed, resulting in a significant cost increase. In addition, industrial processing of these alloys, specifically the TWIP steels with high manganese contents, has proven to be extremely challenging, and the TWIP grades have also been shown to be prone to delayed cracking. ${ }^{25}$

Recent research indicates that the embrittlement susceptibility can be reduced by aluminum alloying, although the exact mechanism involved is still under investigation. ${ }^{25}$ From Figure 4, it is clear that a property gap exists between the currently available AHSS grades of the first and second generations and defines a property band for future third-generation AHSS. Current research is hence focused on filling this property window using modified or novel processing routes where special attention should naturally also be given to industrial feasibility and cost effectiveness. ${ }^{14,15,26}$

\section{Development of high-temperature magnesium alloys}

In addition to the increasing penetration of AHSS, the use of light metals (aluminum and magnesium) in the automobile industry has increased significantly over the past 20 years and is poised for further growth given the increasing emphasis on vehicle fuel economy.

\section{Computational alloy design}

Originating from the early work of Kaufman and Bernstein, ${ }^{27}$ the CALPHAD (calculation of phase diagrams) approach, ${ }^{28,29}$ based on computational thermodynamics, has matured over the past few decades to calculate phase diagrams and predict phase equilibrium for complex multicomponent systems.

\section{Current AHSS developments}

In addition to DP steels, AHSS grades that are currently being applied or are under increased investigation by steel suppliers, include CP and TRIP steels. These three steel grades are referred to as first-generation AHSS. The austenitic stainless steels, TWIP steels, lightweight steels with induced plasticity, and shearband-strengthened steels are referred to as

\begin{tabular}{|c|c|c|}
\hline Material & Weight Reduction (\%) & Relative Cost per Part ${ }^{13}(\%)$ \\
\hline Advanced high-strength steels (AHSS) & $15-25$ & $100-150$ \\
\hline Glass fiber composites & $25-35$ & $100-150$ \\
\hline Aluminum & $40-50$ & $130-200$ \\
\hline Magnesium & $55-60$ & $150-250$ \\
\hline Carbon-fiber composites & $55-60$ & $200-1000$ \\
\hline
\end{tabular}




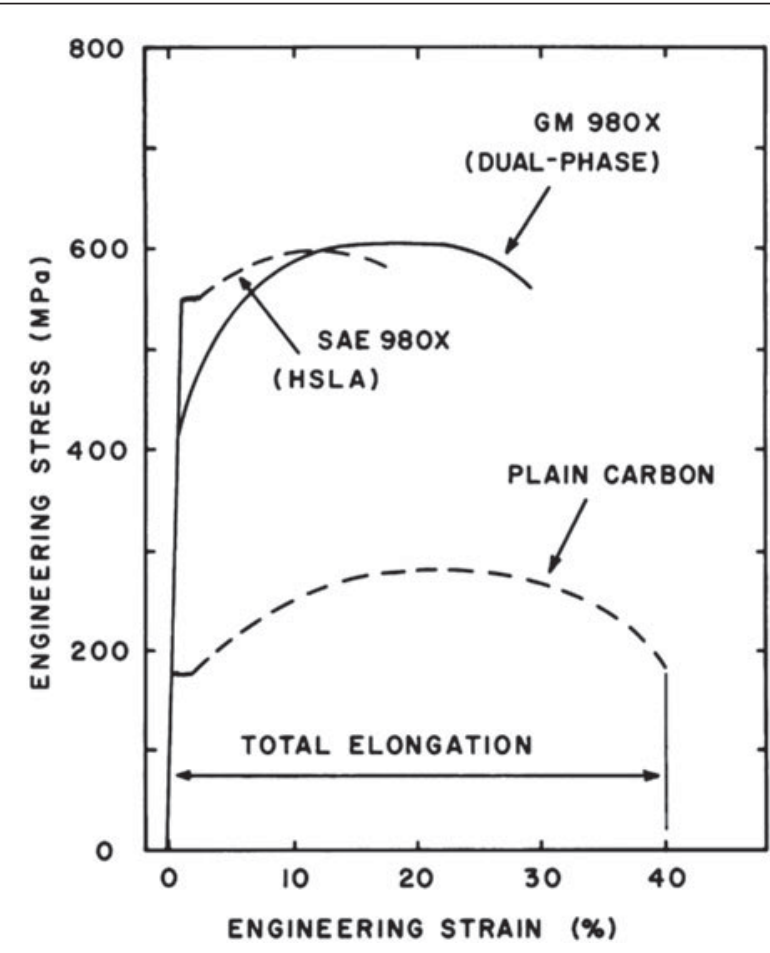

Figure 3. Comparison of the stress-strain curve for a dualphase steel (GM 980X) with those for a plain-carbon steel and a high-strength low-alloy (HSLA) steel (SAE 980X). Reproduced with permission from Reference 17. (C) 1981 TMS-AIME.

Many commercial software packages, such as Thermo-Calc, ${ }^{30}$ FactSage, ${ }^{31}$ and Pandat, ${ }^{32}$ have become important tools in the development of new materials and products.

The CALPHAD approach is based on thermodynamic descriptions (models) of an alloy system that denote a set of thermodynamic parameters for all phases in the system. These models are generally available in CALPHAD databases ${ }^{31-33}$ or can be generated using first-principles calculations. ${ }^{33,34}$ This section describes examples of the application of computational thermodynamics and CALPHAD modeling in the development of new creep-resistant magnesium alloys using the Pandat code and its PanMagnesium database. ${ }^{32}$

\section{Magnesium alloy development}

Aluminum is the most widely used alloying addition in magnesium for strengthening and castability. According to a calculated magnesium-aluminum phase diagram, ${ }^{35}$ two eutectic reactions are important to the phase constitution of magnesiumaluminum binary alloys (L represents liquid):

$$
\begin{array}{ll}
\text { At } 450^{\circ} \mathrm{C} & \mathrm{L} \rightarrow \mathrm{Al}+\mathrm{Mg}_{2} \mathrm{Al}_{3} \\
\text { At } 436^{\circ} \mathrm{C} & \mathrm{L} \rightarrow \mathrm{Mg}+\mathrm{Mg}_{17} \mathrm{Al}_{12} .
\end{array}
$$

Commercial cast and wrought magnesium alloys, AZ91 (Mg-9Al-1Zn*), AM60 (Mg-6Al-0.3Mn), and AZ31

*All compositions in weight percentages unless otherwise stated.
$(\mathrm{Mg}-3 \mathrm{Al}-1 \mathrm{Zn})$, contain less than $10 \mathrm{wt} \%$ aluminum, and the microstructures of these magnesium-aluminum-based alloys are generally characterized by the formation of the $\mathrm{Mg}_{17} \mathrm{Al}_{12}$ phase. The low eutectic temperature $\left(436^{\circ} \mathrm{C}\right)$ of the $\mathrm{Mg}_{17} \mathrm{Al}_{12}$ phase limits the application of magnesium-aluminum alloys to temperatures below $125^{\circ} \mathrm{C}$, above which the discontinuous precipitation of the $\mathrm{Mg}_{17} \mathrm{Al}_{12}$ phase leads to substantial creep deformation. Therefore, possible approaches for improving creep resistance in magnesium-aluminum-based alloys include (1) suppressing the formation of the $\mathrm{Mg}_{17} \mathrm{Al}_{12}$ phase, (2) pinning grain-boundary sliding, and (3) slowing solute diffusion in the magnesium matrix.

Earlier experimental work ${ }^{36,37}$ showed that additions of rare earths (REs) in the form of the uncontrolled-composition RE alloy misch metal can improve the creep resistance of magnesium-aluminum-based alloys, especially when the aluminum content is low (less than $4 \mathrm{wt} \%$ ). This finding led to the development of the AE-series alloys AE42 (Mg-4Al-2RE) and AE44 (Mg-4Al-4RE), where the misch metal generally contains more than $60 \mathrm{wt} \%$ cerium (with a balance of lanthanum, neodymium, and praseodymium). Figure 5 shows the calculated liquidus projection of the magnesium-aluminum-cerium system in the magnesium-rich corner. Generally, the liquidus temperature decreases with aluminum addition (up to at least about $10 \mathrm{wt} \%$ ) and cerium (up to at least about $10 \mathrm{wt} \%$ ), with the following two Type II invariant reactions marked at $598^{\circ} \mathrm{C}$ and $562^{\circ} \mathrm{C}$ :

$$
\begin{array}{ll}
\text { At } 598^{\circ} \mathrm{C} & \mathrm{L}+(\mathrm{Al}, \mathrm{Mg})_{2} \mathrm{Ce} \rightarrow \mathrm{Mg}+\mathrm{Mg}_{12} \mathrm{Ce} \\
\text { At } 562^{\circ} \mathrm{C} & \mathrm{L}+(\mathrm{Al}, \mathrm{Mg})_{2} \mathrm{Ce} \rightarrow \mathrm{Mg}+\mathrm{Al}_{11} \mathrm{Ce}_{3} .
\end{array}
$$

The solidification paths of the AE42 and AE44 alloys calculated using the Scheil model, ${ }^{38}$ based on the assumption of complete mixing in the liquid but no diffusion in the solid, are

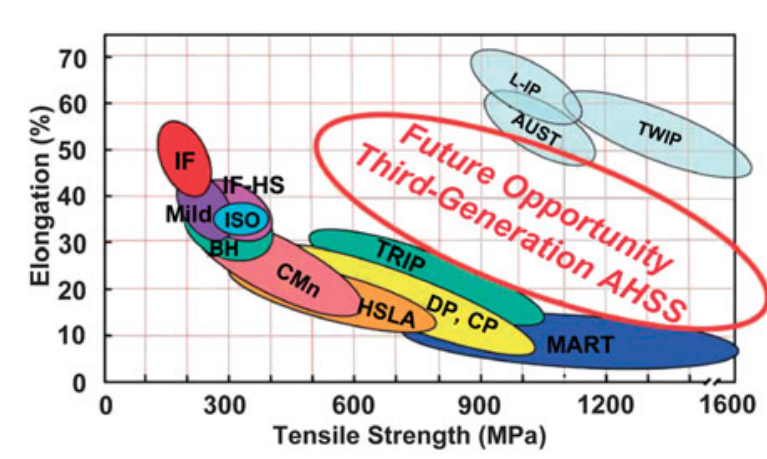

Figure 4. Overview of tensile strength and total elongation combinations for various classes of conventional and advanced high-strength steels (AHSSs). ${ }^{22,23}$ Note: AUST, austenitic; BH, bakehardening; $\mathrm{CP}$, complex-phase; $\mathrm{CMn}$, carbon-manganese; DP, dual-phase steel; HSLA, high-strength low-alloy; IF, interstitialfree; IF-HS, interstitial-free high-strength; ISO, International Organization for Standardization; L-IP, lightweight steel with induced plasticity; MART, martensitic; Mild, plain-carbon; TRIP, transformation-induced plasticity; TWIP, twinning-induced plasticity. Reproduced with permission from Reference 22. (C) 2006 Korean Institute of Metals and Materials. 


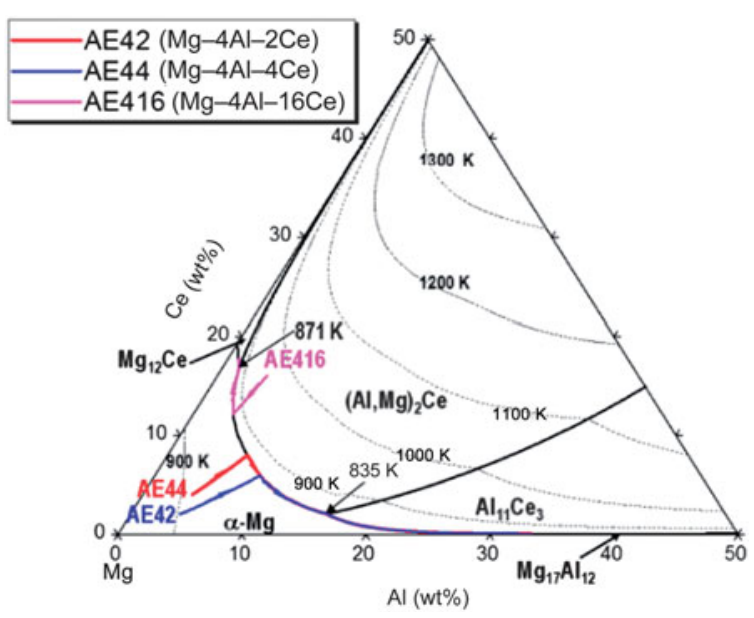

Figure 5. Calculated magnesium-aluminum-cerium liquidus projection and solidification paths of several experimental magnesium-aluminum-cerium alloys. Reproduced with permission from Reference 35. (c) 2013 TMS.

superimposed on the phase diagram shown in Figure 5. Based on the simulation results, the solidification sequence for both alloys is as follows:

Nucleation of primary magnesium $\mathrm{L} \rightarrow \mathrm{Mg}$

Monovariant eutectic reaction

$\mathrm{L} \rightarrow \mathrm{Mg}+(\mathrm{Al}, \mathrm{Mg})_{2} \mathrm{Ce}$

Type II invariant reaction

$\mathrm{L}+(\mathrm{Al}, \mathrm{Mg})_{2} \mathrm{Ce} \rightarrow \mathrm{Mg}+\mathrm{Al}_{11} \mathrm{Ce}_{3}$

Ternary eutectic reaction

$\mathrm{L} \rightarrow \mathrm{Mg}+\mathrm{Al}_{11} \mathrm{Ce}_{3}+\mathrm{Mg}_{17} \mathrm{Al}_{12}$.

It is clear that the additions of $2-4 \mathrm{wt} \%$ cerium to magnesium-aluminum alloys result in the formation of $\mathrm{Al}_{11} \mathrm{Ce}_{3}$ in addition to the $\mathrm{Mg}_{17} \mathrm{Al}_{12}$ phase in the magnesium-aluminum binary system. The calculations also show that it takes about $15 \mathrm{wt} \%$ cerium to completely suppress the formation of the $\mathrm{Mg}_{17} \mathrm{Al}_{12}$ phase in the $\mathrm{Mg}-4 \mathrm{Al}$ alloy.

Figure 5 also shows the solidification sequence of AE416 (Mg-4Al-16Ce) alloy, which follows a different trajectory:

\footnotetext{
Nucleation of $(\mathrm{Al}, \mathrm{Mg})_{12} \mathrm{Ce}$ phase $\quad \mathrm{L} \rightarrow(\mathrm{Al}, \mathrm{Mg})_{2} \mathrm{Ce}$

Monovariant eutectic reaction $\quad \mathrm{L} \rightarrow \mathrm{Mg}+(\mathrm{Al}, \mathrm{Mg})_{2} \mathrm{Ce}$

Type II invariant reaction

Binary eutectic reaction
}

summarized in Table II and compared with the composition of commercial AM50 (Mg-5Al-0.3Mn) alloy. In AE alloys, 4-5 wt $\%$ aluminum is generally needed for die castability, whereas it is very expensive to use $16 \mathrm{wt} \%$ cerium (i.e., AE416 alloy) to suppress the formation of $\mathrm{Mg}_{17} \mathrm{Al}_{12} \cdot{ }^{35} \mathrm{On}$ the other hand, AE44 alloy has a significantly lower fraction of $\mathrm{Mg}_{17} \mathrm{Al}_{12}$ and, thus, exhibits much better high-temperature strength than AE42 and AM50 alloys. Therefore, AE44 alloy was selected for the Chevrolet (GM) Corvette engine cradle (the world's first magnesium chassis component), where the operating temperature approaches $150^{\circ} \mathrm{C} . .^{39}$

\section{Lightweight structures and manufacturing processes}

Utilizing the new materials developed by materials researchers in vehicles requires the parallel development of new manufacturing processes that are robust in terms of quality and capable of global production at scales on the order of millions of units per year. As in the aerospace sector, the structural components are critical for safety, but automobiles also need to be designed to be reliable without inspection for over a decade. This section provides some examples of how lightweight materials, when combined with innovative manufacturing processes, can provide lightweight solutions in automotive chassis and body structures.

\section{Chassis structures}

Lightweight and efficient chassis structures are very important for several key performance attributes, including ride, handling, and noise and vibration control. Over the past 50 years, new aluminum and magnesium alloys and their manufacturing technologies have enabled reduced mass and improved performance and productivity of automotive chassis structures such as the front engine as an example. ${ }^{5}$

With the introduction of lightweight materials, there are always new or improved manufacturing processes to enable applications of these materials. GM introduced the first allwrought-aluminum cradle in the 1999 Chevy Impala. It consisted of 15 extruded sections and two stampings and weighed $18 \mathrm{~kg}$; in comparison, a typical steel-sheet construction has about 48 parts and weighs $28 \mathrm{~kg}$. Advanced robotic aluminum welding technology, namely, pulsed-gas metal arc welding, was used to join the complex extrusions, and this occurred along a welding line of 40 robotic welders in four welding stations. ${ }^{40}$
The eutectic temperatures for the $\mathrm{Al}_{11} \mathrm{Ce}_{3},(\mathrm{Al}, \mathrm{Mg})_{2} \mathrm{Ce}$, and $\mathrm{Mg}_{12} \mathrm{Ce}$ phases were calculated to be $560^{\circ} \mathrm{C}, 622^{\circ} \mathrm{C}$, and $867^{\circ} \mathrm{C}$, respectively, which are all significantly higher than that of the $\mathrm{Mg}_{17} \mathrm{Al}_{12}$ phase $\left(436^{\circ} \mathrm{C}\right)$.

The Scheil model was also used to calculate the fractions of phases formed in the three AE alloys according to the previously shown solidification paths. The results of these calculations are

\begin{tabular}{|l|c|c|c|c|}
\hline \multicolumn{5}{|c|}{ Table II. Scheil simulation of the phase compositions (volume percentages) of } \\
magnesium-aluminum-cerium alloys. \\
\hline Alloy & $(\mathbf{A l}, \mathbf{M g})_{2} \mathbf{C e}$ & $\mathbf{A l}_{11} \mathrm{Ce}_{3}$ & $\mathbf{M g}_{17} \mathbf{A l}_{12}$ & $\mathbf{M g}_{12} \mathbf{C e}$ \\
\hline AM50 & - & - & 4.3 & - \\
\hline AE42 & 0.9 & 0.2 & 1.8 & - \\
\hline AE44 & 2.0 & 0.1 & 1.0 & - \\
\hline AE416 & 9.5 & 0 & 0 & 0.7 \\
\hline
\end{tabular}

aBaseline: AM50 alloy. 
Additional developments include thin-wall and hollow aluminum casting technologies, which have made the aluminum cradle design more efficient and have greatly reduced welding requirements. A good example is the hollow-cast/ extrusion-welded cradle for the GM Cadillac CTS. The method used to produce the thin-wall (4-mm) hollow casting for this cradle is a modified low-pressure permanent mold process in which a steel mold is bottom-fed from a crucible. The vacuum pulls gases from the mold and begins the fill. Pressure is then added to fill the cavity and feed shrinkage, producing extremely sound castings with very low porosity $(<0.5 \%)$ and good weldability. This process can be fully automated for high-volume production. ${ }^{41}$

Another significant process development is high-pressure die casting, which offers attractive flexibility in design and manufacturing. With the excellent die-filling characteristics of magnesium and aluminum alloys, this process allows large, thin-wall, and complex light-metal castings to be produced economically, enabling the replacement of steel structures made of numerous stampings and weldments. The first-in-industry one-piece magnesium die-cast cradle, using AE44 alloy discussed in the section "Magnesium alloy development," for the 2006 Chevrolet (GM) Corvette Z06 weighs only $10.5 \mathrm{~kg}$, a $35 \%$ reduction over the aluminum cradle it replaced.

\section{Body structures}

Over the past 50 years, passenger-car body structures have moved from all-mild-steel-sheet construction to mixed materials, ${ }^{5}$ a transition that was also enabled by advanced materials and manufacturing technologies. In the 1990s, developments in aluminum vacuum die casting, extrusion, and welding/ joining technologies, along with the creation of special cast aluminum alloys such as Aural-2 and Magsimal-59, were key enablers for aluminum-intensive vehicles such as the Audi A8/A2, Acura NSX, and Jaguar XJ.

Over the same time frame, the steel industry made significant advances in steel alloys. Many AHSS grades were developed for automotive applications (see the section "Development of advanced high-strength steels"). In many cases, these steels offer only slightly less weight reduction than aluminum but at a fraction of the cost. AHSSs have made significant inroads, with applications in many light vehicles such as the BMW 7 Series and Lexus LS430. The latest high-volume global vehicle, the Cadillac ATS, makes extensive use of AHSS. The body structure includes $29.6 \mathrm{wt} \%$ DP or multiphase, $22.6 \mathrm{wt} \%$ HSLA, $17.5 \mathrm{wt} \%$ bake-hardened, $5.7 \mathrm{wt} \%$ press-hardened, and $4.8 \mathrm{wt} \%$ martensite steels. ${ }^{42}$

\section{Vacuum die casting}

Despite the high productivity of conventional high-pressure die casting, the greatest drawback of this process (for aluminum or magnesium) is the high porosity level in the obtained parts due to entrapped gases resulting from the injection of molten metal at very high velocities during die casting. The porosity issue is less serious for thin-wall sections $(<2.5 \mathrm{~mm})$, where the mechanical properties are largely provided by the fine-grained and pore-free casting skins. When thicker walls are needed for stiffness or durability in critical structural applications, the effects of porosity on mechanical properties (especially ductility and fatigue strength) are more serious. However, alternative processes can produce castings with less porosity, although often at higher cost or lower productivity.

Vacuum die casting is an advanced process in which reduced pressure created in the injection chamber and die cavity just prior to injection leaves no entrapped air in the casting, thereby enabling the manufacture of relatively large thin-wall castings with significantly improved properties. Castings produced by this process are currently targeted for components that require pressure tightness and good mechanical properties upon heat treatment. Vacuum die casting thus stretches the capabilities of conventional die casting while preserving its economic benefits. ${ }^{43}$

Alcan's patented High-Q-Cast process, a vacuum highpressure die-casting process, has been used in high-volume aluminum casting production of automotive body parts such as the Audi A2 B pillar, one of the most critical body components. New aluminum alloys, such as Aural-2, Silafont-36, and Magsimal-59, have been specifically developed for highvacuum die-casting processes. ${ }^{44,45} \mathrm{GM}$ introduced its first cast aluminum shock tower in its 2013 Cadillac ATS, ${ }^{46}$ as shown in Figure 6, which weighs $2.8 \mathrm{~kg}$ and represents a weight savings of about $50 \%$ from a comparable design of sheet-steel construction.

One important requirement for thin-wall structural castings is high ductility ( $>10 \%$ elongation), which is needed for joining processes (typically self-pierce riveting, a process using a rivet that makes its own hole as it is being inserted during joining). Iron is a common impurity element and can form the brittle iron-rich intermetallic phase $\beta-\mathrm{Al}_{5} \mathrm{FeSi}$ in cast aluminum alloys. On the other hand, a certain amount of iron is desired in cast aluminum alloys for high-pressure die casting, because it reduces the tendency for die soldering and also improves the hot-tearing resistance. ${ }^{47,48}$ It is thus a common practice to add manganese to aluminum alloys to modify the $\beta-\mathrm{Al}_{5} \mathrm{FeSi}$ intermetallic.

A number of studies on the effects of manganese addition and the cooling rate on iron-rich intermetallic phases have been reported for several alloy systems. ${ }^{48-50} \mathrm{~A}$ recent study, ${ }^{51}$ based on CALPHAD modeling of the aluminumsilicon-magnesium-iron-manganese system, revealed the relationship between the iron concentration and the amount of manganese required to eliminate the $\beta-\mathrm{Al}_{5} \mathrm{FeSi}$ phase. The simulation results and experimental validation suggested that an iron-to-manganese ratio of less than 1 can effectively eliminate the $\beta-\mathrm{Al}_{5} \mathrm{FeSi}$ phase in the as-cast microstructure. This finding provides an important basis for controlling the ductility of aluminum castings. 


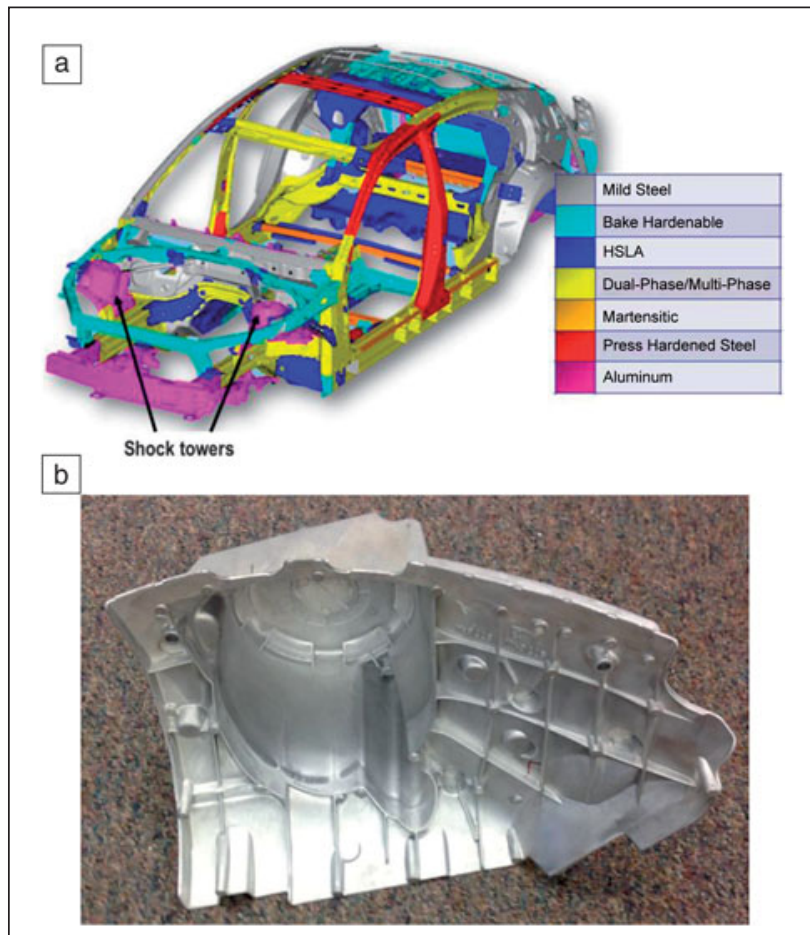

Figure 6. (a) Multimaterial body structure for 2013 Cadillac ATS showing the locations of two cast aluminum shock towers. ${ }^{46}$ (b) Aluminum shock tower casting for 2013 Cadillac ATS (approximate size: $542 \mathrm{~mm} \times 303 \mathrm{~mm} \times 35 \mathrm{~mm}$ ). (a) Reproduced with permission from Reference 46. (c) 2012 Steel Market Development Institute. (b) Courtesy of GM.

\section{Fiber-reinforced polymer composites and processing}

Carbon-fiber-reinforced polymer composites offer a very weight-effective engineering solution for body structures. The 2011 commercial introduction of an airframe containing significant amounts of carbon-fiber-reinforced polymer composite for the commercial Boeing Dreamliner aircraft raises the question of whether the automotive industry will follow this trend. Such a move would require a breakthrough cost reduction, given that the owner of a commercial aircraft will see a payback of approximately USD $\$ 400$ per kilogram (180 USD\$/lb) weight reduction, ${ }^{52,53}$ which is more than 100 times greater than that for a light-vehicle owner. ${ }^{54}$ Achieving the cost level required for automotive use demands a dramatic reduction in the cost of the carbon fiber and the cost of producing the composite component. ${ }^{55}$

Materials science and engineering has enabled a continuous improvement in carbon-fiber performance and cost. ${ }^{56}$ In 1879 , Thomas Edison, for the first time, used carbon-fiber filaments in his early incandescent light bulbs. During World War II, the Union Carbide Corporation began investigating the fabrication of high-performance carbon fibers. Two manufacturing processes for high-strength and high-modulus carbon fibers from rayon and polyacrylonitrile precursor fibers were developed in 1959 and 1962, respectively. In 1963, pitch-derived carbon fibers, with high-modulus properties, were invented. The precursor material is generally processed by a combination of stretching and hightemperature heat treatment. The resulting fibers are highly graphitized and exhibit a modulus in the range of 200-500 GPa with tensile strengths ranging from $3 \mathrm{GPa}$ to $7 \mathrm{GPa}$.

Unfortunately, the costs of the precursors and the heat treatment are high, which has limited the use of carbon fibers in automotive products. Extensive research is under way to develop fibers from lower-cost precursors, including lignin, which is second only to cellulose in natural abundance, readily available, and relatively inexpensive. ${ }^{57-60}$

Developing a lower-cost carbon fiber is only one element of meeting automotive requirements. For over 50 years, automakers have been making automotive components from lower-cost glass-fiber-reinforced automotive components. However, production has been limited to low-volume components and composite-intensive niche vehicles. Although processing of polymer composites offers significant savings in tooling costs compared to metal components, the processing times are not compatible with large-scale production. ${ }^{5}$

The 1953 Corvette represents the first widespread application of fiber-reinforced polymer (FRP) in a production automobile. ${ }^{61}$ Beginning in June 1953, 300 Corvettes were produced with FRP body panels made using the open-mold process developed for the boat-building industry. This involved hand rolling polyester resin into glass-fiber mats and was found to be too slow for the volume of vehicles required, leading Chevrolet to scour the FRP industry for faster-capability molding processes (such as injection molding, compression molding, liquid molding, and thermoforming).

The molded fiber glass (MFG) process was ultimately chosen using matched metal die molding, which was capable of making up to 100 parts per day in a single tool. For simple shaped parts, preforms were made from fiberglass mats; for more complicated or deep-drawn parts, preforms were prepared by hand spraying chopped fiberglass strands onto a shaped screen. The molding was accomplished by placing the fiberglass preform into the tool, hand spreading a measured quantity of polyester resin (the charge) onto the preform, and then closing the mold. After a 3-min cure, the molded part could be pulled from the tool, and the extra material at the edges, called flash, removed with a hand-held electric sander.

Despite all of the improvements made in composites processing since the first Corvette, comparatively long cycle times still limited applications to lower-volume vehicles heading into the 1980s. The introduction of sheet molding compound (SMC) allowed for shorter molding cycle times. SMC is a combination of chopped glass strands and filled polyester resin in the form of a sheet that is formed into the component shape by compression or injection molding. The 5-min cycle time required in MFG preform molding in 1953 had been reduced to $3 \mathrm{~min}$ for a typical SMC molding by 1983 . Between 1983 and 1988, however, several process improvements were developed to further reduce cycle time. ${ }^{62}$

Vacuum-assisted molding was a key technology developed for shorter cycles. Removing the air before closing the press 
allowed for the use of thinner, higher-die-coverage charge patterns without fear of air entrapment and blister formation. Thinner charges allowed for faster mold closing times, which, in turn, enabled faster chemistries that would otherwise have led to premature polymerization, resulting in a viscosity increase that would inhibit mold filling.

Perhaps even more significantly, vacuum-assisted molding led to improved surface quality and allowed for the elimination of in-mold coating. This change alone accounted for a $30 \%$ cycle-time improvement. ${ }^{63}$ In the mid-1980s, improved microprocessor controls gave SMC presses unprecedented control of platen parallelism and closing speed. These presses generated tighter tolerances in part thickness and therefore enabled thinner wall sections to be molded. ${ }^{64}$ In addition to providing cost and mass reductions, thinner parts also enabled shorter cycle times. By 1988, press improvements in combination with vacuum-assisted molding enabled SMC productivity to finally meet the elusive 60 -s cycle time that translates into more than 250,000 parts per year from a single tool (see Figure 7).

For higher-performance components, resin transfer molding and structural reaction injection molding are used. ${ }^{65}$ These processes have the advantages of minimizing fiber scrap, accommodating part complexity, and having relatively high processing rates. Fiberglass-mat precut patterns are placed in the female (typically concave) tool. The male tool is hydraulically forced into the female tool. Through pressure, the resin flows through the part. After the resin has cured, the male tool is removed, and the part is taken out. This process allows for engineered preforms to be used and also enables greater control of part thickness. Another benefit of this process is that both surfaces have a very low surface roughness to allow for flawless appearance when the part is painted (i.e., a Class A finish).

There are increasing reports in the literature that significant improvements in multiple structural functions can be achieved with new hybrid multiscale composites. These structures incorporate nanoscale reinforcements such as carbon nanotubes within a carbon-fiber composite. This approach combines fiber-dominated properties in the longitudinal direction with

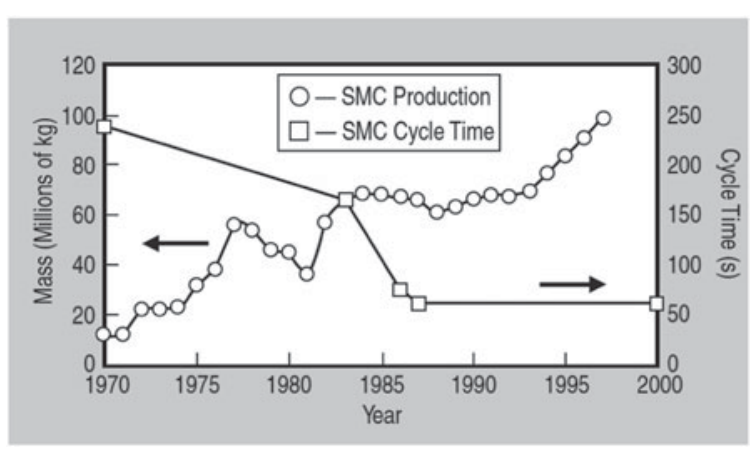

Figure 7. Changes in cycle time and production of automotive sheet molding compound (SMC) from 1970 to 2000. Reproduced with permission from Reference 5. (c) 2007 Springer. improved matrix-dominated transverse properties. The improved transverse properties are obtained by replacing the neat resin polymer matrix with a nanocomposite matrix or by growing the carbon nanotubes on the surface of the fibers. ${ }^{66-68}$

\section{Future outlook}

The challenge of designing the next generation of lighterweight vehicles is putting increased pressure on automotive manufacturers to expedite the implementation of new materials. As one example, to more quickly develop new, robust, and lower-cost manufacturing methods, the US government is supporting the creation of a network of manufacturing innovation institutes (National Network for Manufacturing Innovation, NNMI). ${ }^{69}$ Two of these institutes, Lightweight Innovations for Tomorrow and the Institute for Advanced Composites Manufacturing Innovation, are specifically focused on the structural materials described in this article. ${ }^{70,71}$ The Fraunhofer Institutes, which are the largest application-oriented research organizations in Europe, perform a similar role. ${ }^{72}$ These institutes are taking on the challenge of accelerating the movement of new materials from the laboratory to commercial implementation. Scientists and engineers from academia, nonprofit and federal laboratories, and industry are utilizing the latest integrated computational materials engineering methodologies combined with state-of-the-art pilot-scale manufacturing equipment to produce the next generation of affordable lightweight material structures.

\section{References}

1. R.B. Folsom, "Henry Ford," in The Automobile Industry, 1896-1920, G.S. May, Ed. (Facts on File, New York, 1990), pp. 192-222.

2. Ward's Automotive International Yearbook (Ward's Communications, Detroit, 1955), p. 29.

3. "The Year 1955 from the People History," http://www.thepeoplehistory. com/1955.html (accessed September 2015).

4. A.M. Kesslerjan, "2014 Auto Sales Jump in U.S., Even with Recalls," New York Times (January 5, 2015)

5. A.I. Taub, P.E. Krajewski, A.A. Luo, J.N. Owens, JOM 59 (2), 48 (2007)

6. L. Brooke, Automot. Eng. Int. 2 (5), 18 (2015).

7. W.J. Joost, JOM 64 (9), 1032 (2012).

8. "2010 Annual Progress Report: Lightweighting Material" (US Department of Energy, Washington, DC, 2010), http://www1.eere.energy.gov/vehiclesandfuels/ pdfs/program/2010_lightweighting_materials.pdf (accessed September 2015). 9. "Light-Duty Automotive Technology, Carbon Dioxide Emissions, and Fuel Economy Trends: 1975 through 2014: Executive Summary" (EPA Publication 420-S-14-001, October 2014), http://www.epa.gov/fueleconomy/fetrends/19752014/420s14001.pdf (accessed September 2015).

10. M.W. Verbrugge, T.M. Lee, P.E. Krajewski, A.K. Sachdev, C. Bjelkengren, R. Roth, R. Kirchain, Mater. Sci. Forum 618-619, 411 (2009).

11. "Weight Reduction with Aluminum: Part of All Cost-Effective Fuel Economy Improvement Strategies" (Scenaria, Plymouth, MI, 2012), http://www. drivealuminum.org/research-resources/PDF/Research/2012/2012-ScenariaStudy\%20.pdf (accessed September 2015).

12. "2015 North American Light Vehicle Aluminum Content Study: Executive Summary" (Ducker Worldwide, Troy, MI, 2014), http://www.drivealuminum. org/research-resources/PDF/Research/2014/2014-ducker-report (accessed September 2015)

13. W. Joost, "Energy, Materials, and Vehicle Weight Reduction" (US Department of Energy, Washington, DC, 2015), http://www.nist.gov/mml/acmd/structural_ materials/upload/Joost-W-DOE-VTP-NIST-ASP-AHSS-Workshop-R03.pdf (accessed September 2015).

14. E. De Moor, P.J. Gibbs, J.G. Speer, D.K. Matlock, J.G. Schroth, AIST Trans. 7 (11), 133 (2010).

15. P.J. Gibbs, E. De Moor, M.J. Merwin, B. Clausen, J.G. Speer, D.K. Matlock, Metall. Mater. Trans. A 42, 12, 3691 (2011). 
16. D.K. Matlock, J.G. Speer, E. De Moor, P.J. Gibbs, "Recent Developments in Advanced High Strength Sheet Steels for Automotive Applications: An Overview," presented at the International Iron \& Steel Symposium, Karabük, Türkiye, April 2-4, 2012

17. M.S. Rashid, B.V.N. Rao, Conf. Proc. Fundamen. Dual-Phase Steels Symp., R.A. Kot, B.L. Bramfitt, Eds. (TMS-AIME, Warrendale, PA, 1981), pp. 249-264.

18. R.A. Kot, J.W. Morris, Eds., Structure and Properties of Dual-Phase Steels (TMS-AIME, Warrendale, PA, 1979).

19. R.A. Kot, B.L. Bramfitt, Eds., Conf. Proc. Fundamen. Dual-Phase Stee/s Symp. (TMS-AIME, Warrendale, PA, 1981).

20. A.T. Davenport, Ed., Formable HSLA and Dual-Phase Steels (TMS-AIME, Warrendale, PA, 1979).

21. A.R. Marder, in Formable HSLA and Dual-Phase Steels, A.T. Davenport, Ed. (TMS-AIME, Warrendale, PA, 1979), p. 87.

22. D.K. Matlock, J.G. Speer, "Design Considerations for the Next Generation of Advanced High Strength Sheet Steels," Proc. 3rd Int. Conf. Struct. Steels, H.C. Lee, Ed. (Korean Institute of Metals and Materials, Seoul, Korea, 2006), pp. $774-781$

23. S. Keeler, M. Kimchi, Eds., Advanced High-Strength Steel (AHSS) Application Guidelines Version 5.0 (WorldAutoSteel, Middletown, OH, 2014), www. worldautosteel.org/projects/advanced-high-strength-steel-applicationguidelines (accessed September 2015).

24. L. Brooke, H. Evans, Automot. Eng. Int. 117, 16 (2009).

25. S.K. Kim, G. Kim, K.-G. Chin, "Development of High Manganese TWIP Steel with 980MPa Tensile Strength," Proc. Int. Conf. New Dev. Adv. High-Strength Sheet Steels (AIST, Orlando, FL, 2008), p. 249.

26. D.K. Matlock, J.G. Speer, Mater. Manuf. Proc. 25 (1), 7 (2010)

27. L. Kaufman, H. Bernstein, Computer Calculation of Phase Diagrams with Special Reference to Refractory Metals (Academic Press, New York, 1970).

28. Y.A. Chang, S. Chen, F. Zhang, X. Yan, F. Xie, R. Schmid-Fetzer, W.A. Oates, Prog. Mater. Sci. 49, 313 (2004).

29. Y.A. Chang, Y. Yang, in Methods for Phase Diagram Determination, J.-C. Zhao, Ed. (Elsevier, Oxford, UK, 2007), chap. 8, pp. 273-291.

30. Thermo-Calc Software, http://www.thermocalc.com (accessed September 2015).

31. FactSage 6.4, http://www.factsage.com (accessed September 2015).

32. CompuTherm LLC, http://www.computherm.com (accessed September 2015)

33. Z.K. Liu, J. Phase Equilib. Diffus. 30 (5), 517 (2009).

34. J.E. Saal, S. Kirklin, M. Aykol, B. Meredig, C. Wolverton, JOM 65, 1501 (2013) 35. A.A. Luo, "Application of Computational Thermodynamics and CALPHAD in Magnesium Alloy Development," Proc. 2nd World Congr. Integr. Comput. Mater. Eng., M. Li, C. Campbell, K. Thornton, E. Holm, P. Gumbsch, Eds. (TMS, Warrendale, PA, 2013), pp. 3-8.

36. W.E. Mercer II, "Magnesium Die Cast Alloys for Elevated Temperature Applications" (SAE Tech. Pap. 900788, SAE International, Warrendale, PA, 1990).

37. P. Bakke, H. Westengen, in Magnesium Technology 2005, N.R. Neelameggham, Ed. (TMS, Warrendale, PA, 2005), p. 291

38. D.A. Porter, K.E. Easterling, M.Y. Sherif, Phase Transformations in Metals and Alloys, 3rd ed. (Taylor \& Francis/CRC Press, Boca Raton, FL, 2009).

39. J. Aragones, K. Goundan, S. Kolp, R. Osborne, L. Ouimet, W. Pinch, "Development of the 2006 Corvette Z06 Structural Cast Magnesium Crossmember" (SAE Tech. Pap. 2005-01-0340, SAE International, Warrendale, PA, 2005).

40. D. Triantos, M. Michaels, "Design and Fabrication of an Aluminum Engine Cradle for a General Motors Vehicle" (SAE Tech. Pap. 1999-01-0659, SAE International, Warrendale, PA, 1999).
41. R. Borns, D. Whitacre, "Optimizing Designs of Aluminum Suspension Components using an Integrated Approach" (SAE Tech. Pap. 2005-01-1387, SAE International, Warrendale, PA, 2005).

42. W.J. Parsons, "Body Structure Light-Weighting at Cadillac," presented at Great Designs in Steel 2013, Livonia, MI, May 1, 2013.

43. E.J. Vinarcik, High Integrity Die Casting Processes (Wiley, New York, 2003). 44. Z. Brown, B. Szymanowski, M. Musser, D. Saha, S. Seaver, Proc. Int. Die Casting Congr. Expo. 2007 (NADCA, Arlington Heights, IL, 2007), p. 154.

45. F. Casarotto, A.J. Franke, R. Franke, in Advanced Materials in Automotive Engineering, J. Rowe, Ed. (Woodhead Publishing, Cambridge, UK, 2012), p. 109. 46. W.J. Parsons, "Light-Weighting the 2013 Cadillac ATS Body Structure," presented at Great Designs in Steel 2012, Livonia, MI, May 16, 2012.

47. D. Apelian, Aluminum Cast Alloys: Enabling Tools for Improved Performance (NADCA, Wheeling, IL, 2009).

48. J.A. Taylor, Procedia Mater. Sci. 1, 19 (2012)

49. C.M. Dinnis, J.A. Taylor, A.K. Dahle, Metall. Mater. Trans. A 37, 3283 (2006). 50. L. Ceschini, I. Boromei, A. Morri, S. Seifeddine, I.L. Svensson, J. Mater. Proc. Technol. 209, 5669 (2009).

51. E. Cinkilic, W. Sun, A.D. Klarner, A.A. Luo, "Use of CALPHAD Modeling in Controlling Microstructure of Cast Aluminum Alloys," presented at the 119th Metal Casting Conference, Columbus, OH, April 20-23, 2015, paper 15-044.

52. C. Red, "Aviation Outlook: Fuel Pricing Ignites Demand for Composites in Commercial Transports," CompositesWorld (July 2008).

53. M. Kaufman, "Cost/Weight Optimization of Aircraft Structures," thesis, KTH Royal Institute of Technology, Stockholm, Sweden (2008).

54. Materials Research to Meet 21st Century Defense Needs (National Academies Press, Washington, DC, 2003).

55. S. Das, "The Cost of Automotive Polymer Composites: A Review and Assessment of DOE's Lightweight Materials Composites Research" (Report ORNL/TM-2000/283, Oak Ridge National Laboratory, Oak Ridge, TN, 2001). 56. S.-J. Park, Carbon Fibers, Springer Series in Materials Science (Springer, Dordrecht, The Netherlands, 2015), vol. 210.

57. J.F. Kadla, S. Kubo, R.A. Venditti, R.D. Gilbert, A.L. Compere, W. Griffith, Carbon 40, 2913 (2002)

58. D.A. Baker, N.C. Gallego, F.S. Baker, J. Appl. Polym. Sci. 124, 227 (2012).

59. J.L. Braun, K.M. Holtman, J.F. Kadla, Carbon 43, 385 (2005).

60. X. Dong, C. Lu, P. Zhou, S. Zhang, L. Wang, D. Li, RSC Adv. 5, 42259 (2015).

61. B. Miller, Plast. World 54 (10), 39 (1996).

62. R.L. Smith, "High-Volume SMC Exterior Body Panels-An Evolution in Productivity" (SAE Tech. Pap. 880360, SAE International, Warrendale, PA, 1988). 63. S. Wood, Mod. Plast. 61 (10), 48 (1984).

64. S. Wood, Mod. Plast. 61 (2), 46 (1984).

65. E.R.H. Fuchs, F.R. Field, R. Roth, R.E. Kirchain, Compos. Sci. Technol. 68, 1989 (2008).

66. R.F. Gibson, Compos. Struct. 92, 2793 (2010).

67. A. Godara, L. Mezzo, F. Luizi, A. Warrier, S.V. Lomov, A.W. van Vuure, L. Gorbatikh, P. Moldenaers, I. Verpoest, Carbon 47, 2914 (2009).

68. A.M. Díez-Pascual, M. Naffakh, C. Marco, M.A. Gómez-Fatou, G.J. Ellis, Curr. Opin. Solid State Mater. Sci. 18, 62 (2014).

69. "National Network for Manufacturing Innovation: A Preliminary Design" (National Science and Technology Council, Washington, DC, January 2013).

70. Lightweight Innovations for Tomorrow, http://www.lift.technology (accessed August 2015)

71. Institute for Advanced Composites Manufacturing Innovation, http://www. iacmi.org (accessed August 2015)

72. "Making Cars that are Lightweight and Crash-Safe," Fraunhofer Research News (August 2013), Topic 5.

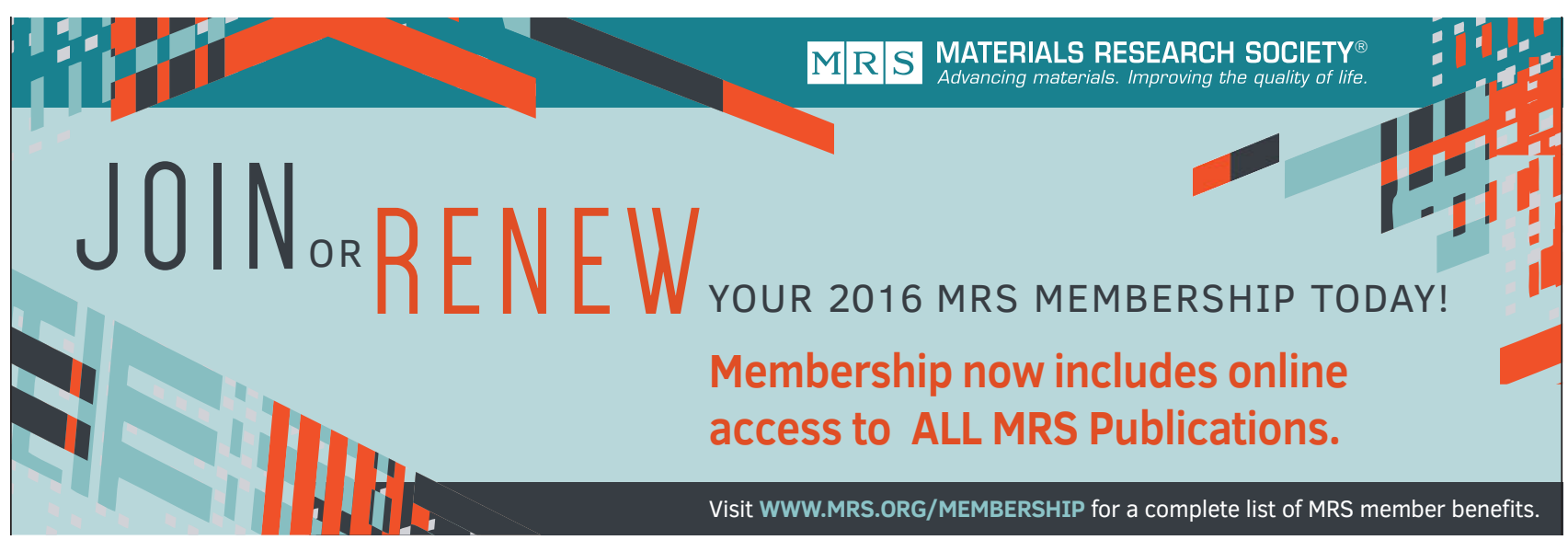




\section{CAMBRIDGE}

\section{Stay up to date with the best in Academic Publishing with Cambridge University Press}

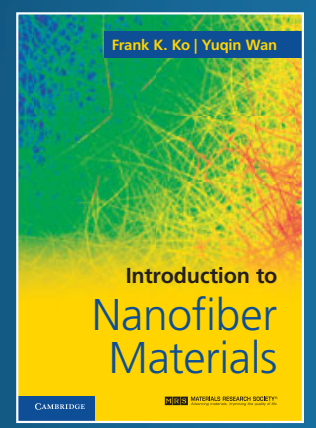

Introduction to Nanofiber Materials

Frank K. Ko, Yuqin Wan Hardback | 9780521879835 £65.00| $\$ 99.00$

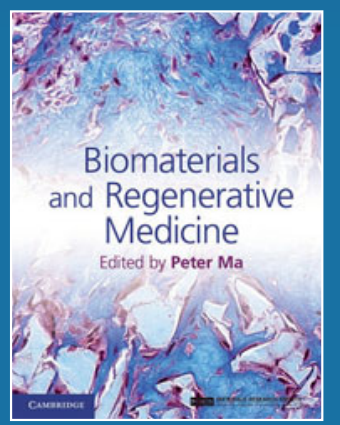

Biomaterials and Regenerative Medicine

Peter X. Ma Hardback | 9781107012097 $£ 115.00 \mid \$ 185.00$

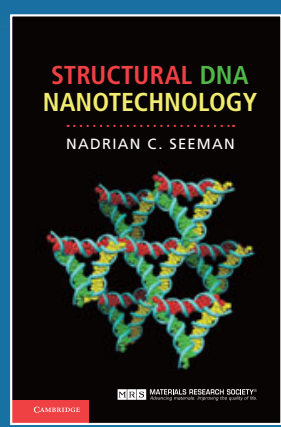

Structural DNA Nanotechnology Nadrian C. Seeman Hardback | 9780521764483 c.£39.99 | c.\$65.99

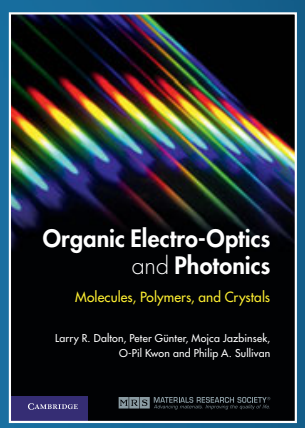

Organic ElectroOptics and Photonics Molecules, Polymers and Crystals Larry R. Dalton, Peter Günter, Mojca Jazbinsek, O-Pil Kwon,

Philip A. Sullivan

Hardback | 9780521449656

£49.99 | \$79.99

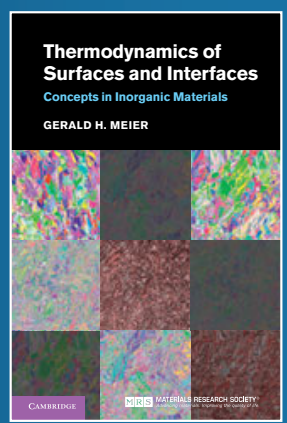

Thermodynamics of Surfaces and Interfaces

Concepts in Inorganic Materials Gerald H. Meier Hardback | 9780521879088 $£ 75.00 \mid \$ 120.00$

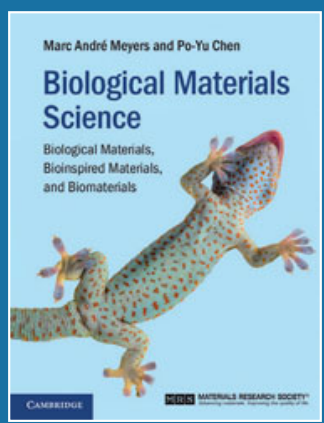

Biological Materials Science

Biological Materials, Bioinspired Materials, and Biomaterials

Marc André Meyers, Po-Yu Chen Hardback | 9781107010451 $£ 60.00 \mid \$ 99.00$

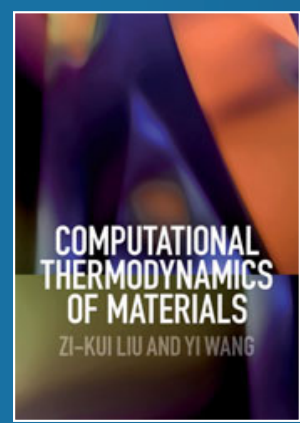

Computational Thermodynamics of Materials

Zi-Kui Liu, Yi Wang Hardback | 9780521198967 Available from February 2016 c.£44.99 | c.\$89.99

For details of all Cambridge titles in Materials Science and related fields, look out for our 2016 Engineering catalogue - available from January. 